\title{
TÜRK HUKUKUNDA ÇEVRE HAKKININ BİREYSEL BAŞVURU YOLUYLA KORUNMASI
}

\author{
Dr. Öğr. Üyesi Bahar KONUK SOMMER*
}

\section{ÖZET}

Çevrenin korunması ve geliştirilmesini amaç edinen çevre hakkına ilk kez, 1972 tarihli Birleşmiş Milletler Stockholm Konferansı sonrası ortaya konan Bildiride, insanın kendisine onurlu ve iyi bir hayat sürmeye olanak veren nitelikli bir çevrede yaşama hakkına sahip olduğunun öngörülmesi suretiyle yer verilmiştir. Dayanışma hakları olarak da adlandırılan üçüncü kuşak haklar arasında yer alan çevre hakkı, 1982 Anayasasının 56. maddesinde "Sosyal ve Ekonomik" haklar başlığı altında düzenlenmiştir. Anayasada 2010 yılında yapılan değişiklikle Anayasada ve Avrupa İnsan Hakları Sözleşmesi’nde düzenlenen hakların ihlal edildiği iddiasıyla Anayasa Mahkemesine bireysel başvuru yapılması mümkündür. Her ne kadar çevre hakkı Avrupa İnsan Hakları Sözleşmesi'nde açıç̧a düzenlenmemişse de, Avrupa İnsan Hakları Mahkemesi, içtihat yoluyla çevre hakkını Sözleşme içerisinde düzenlenen diğer haklarla ilişkilendirerek çevrenin korunmasını güvence altına almaktadır. Anayasa Mahkemesi de çevre hakkının korunmasına yönelik önüne gelen başvuruları, sağlıklı bir çevrede yaşamayı Anayasanın 17. maddesinde düzenlenen maddi ve hakkının bir parçası olarak değerlendirmek suretiyle incelemektedir.

Anahtar Kelimeler: Çevre Hakkı, Bireysel Başvuru, Anayasa Mahkemesi, Avrupa İnsan Hakları Sözleşmesi, Anayasal Çevre Koruma.

Yaşar Üniversitesi Hukuk Fakültesi, Anayasa Hukuku Anabilim Dalı, bahar.konuk@yasar.edu.tr, ORCID ID: 0000-0002-0320-5947,

(Geliş Tarihi: 14.03.2019 - Kabul Tarihi: 02.06.2019) 


\title{
THE PROTECTION OF THE RIGHT TO ENVIRONMENT THROUGH INDIVIDUAL APPLICATION IN TURKISH LAW
}

\begin{abstract}
The right to environment, which aims to protect and improve the environment, was first mentioned in the Declaration issued after the United Nations Conference in Stockholm in 1972 by stipulating that a person has the right to live in a decent environment which allows him to live a dignified and good life. The right to environment, which is also referred to as the third generation rights, also called solidarity rights, is regulated under the heading of economic and social rights in the Article 56 of the Turkish Constitution. The amendment to the Turkish Constitution in 2010 made it possible for everyone to apply to the Constitutional Court by individual application on the grounds that one of the fundamental rights and freedoms within the scope of the European Convention on Human Rights which are guaranteed by the Constitution has been violated by public authorities. Although the right to the environment is not explicitly regulated in the European Convention on Human Rights, the European Court of Human Rights guarantees the protection of the environment by assessing the right to the environment with other rights regulated by the Convention. The Constitutional Court examines the applications for the protection of the right to environment by evaluating it as a part of the right to life and the right to protect and improve someone's corporeal and spiritual existence regulated in Article 17 of the Constitution.
\end{abstract}

Keywords: Right to Environment, Individual Application, Constitutional Court, European Convention on Human Rights, Constitutional Environmental Protection. 


\section{I. ÇEVRE HAKKININ TANIMI VE HUKUKU NITTELIĞİ}

Çevre hakkı, en geniş anlamıyla çevrenin korunmasını ve geliştirilmesini amaç edinen bir haktır ${ }^{2}$. Çevrenin, spesifik bir hakkın konusu olarak düzenlenmesinin temelinde, günümüzde karşılaşılan çevre sorunlarının ve çevresel bozulmaların, ulusal ve uluslararası düzeyde, insan sağlığına yönelik ciddi bir tehdit haline gelmiş olması yatar³. Şüphesiz ki bir hak, o hakka sahip olan herkesin haktan yararlanmasını sağlayacak düzenlemelerin yapıldığı ve koruma mekanizmaları üretildiği zaman güvence altına alınmış olur. Bu nedenle çevre hakkına ilişkin düzenlemelere hem ulusal hem de uluslararası belgelerde yer verilmiştir.

Uluslararası hukuk alanında çevre hakkı ilk defa Birleşmiş Milletler Örgütü’nün 1972 tarihli Stockholm Konferansı'nda dile getirilmiştir. Konferans sonucunda ortaya konan bildirinin 1. maddesine göre, "İnsan, onurlu ve iyi bir yaşam sürmeye olanak veren nitelikli bir çevrede, özgürlük, eşitlik ve yeterli yaşam koşulları temel hakkına sahiptir”. Böylelikle ilk kez bir bildiride sağlıklı bir çevrede yaşama hakkı karara bağlanmış, konferansa katılan devletler çevre hakkını bireysel bir hak olarak tanımışlardır. Bir başka deyişle, Stockholm Bildirisi'nin 1. maddesinde yer alan düzenleme ile insan hakları ile çevrenin korunması arasında bağ kurulmuş olmaktadır ${ }^{4}$. Öte yandan, çevre hakkının bir insan hakkı olarak kabulüne ilişkin öğretide, ekosantrik veya biyosentrik yaklaşım adı verilen ve çevre sorunlarına yaklaşırken insan yerine çevrenin kendisinin başlı başına bir değer olarak alınması gerektiği görüşünü savunan yazarlarca getirilen eleştiriler de vardır ${ }^{5}$. Bununla birlikte, günümüzde çevre hakkına ilişkin en temel ve yaygın kabulün, hakkın asıl öznesinin çevrenin kendisi olduğu, ancak bu hak yoluyla sağlanacak korumanın, insanların sahip oldukları yaşam ve sağlık hakları vasıtasıyla gerçekleştirilebileceği, dolayısıyla sağlıklı bir çevrede yaşama hakkının temel bir insan hakkı olduğu söylenebilir 6 .

Güneş, Ahmet (2009) “Alman Çevre Hukukunun Anayasal Çerçevesi”, Ankara Üniversitesi Hukuk Fakültesi Dergisi, C: 58, S: 4, s. 783.

3 Özdek, Yasemin (1993) İnsan Hakkı Olarak Çevre Hakkı, Ankara, Türkiye ve Orta Doğu Amme İdaresi Enstitüsü Yayınları No: 249, s. 88; Ertaş, Şeref (2012) Çevre Hukuku ve Hayvan Hakları Hukuku, İleri, s. 81-82; Aygörmez Uğurlubay, Gülsün (2015) Çevreye Karşı Suçlar Türk ve Alman Hukukunda Güncel Sorunlar, Yetkin Yayınları, s. 30.

4 Shelton, Dinah (1991) "The Right to Environment": Eide, Asborn/Helgesen, Jan, The Future of Human Rights Protection in a Changing World, Oslo, Norwegian University Press, s. 202.

5 Leib Hajjar, Linda (2011) Human Rights and the Environment, Martinus Nijhoff Publishers, s. 28-29.

6 Turgut, Nükhet (2001) Çevre Hukuku, Ankara, Savaş Yayınevi, s. 157. 
Çevre hakkı, insan hakları teorisi bakımından dayanışma hakları olarak da adlandırılan üçüncü kuşak haklar arasında yer alır ${ }^{7}$ Çevre hakkının yanı sıra barış hakkı, gelişme hakkı ve insanlığın ortak mirasından yararlanma hakkı gibi hakların yer aldığı üçüncü kuşak haklardan kaynaklanan problemlerin üstesinden tek başına devletlerin veya insanların gelmesi mümkün değildir. Bu problemler ancak dayanışma içerisinde çözülebilir

Çevre hakkının geleneksel insan haklarından önemli farklılıkları bulunmaktadır 9 . Bu farklılıkların temelinde, çevre hakkının zamansal ve yersel kısıtlamalara tabi tutulamaması yatar. Çevre hakkının zamansal kısıtlamaya tabi tutulamaması, hakkın şimdiki nesillerle birlikte gelecek nesillere de ait olmasını ifade eder. Bireyler, topluluklar, devlet ve gelecek nesiller çevre hakkının özneleridir. Çevre hakkı bir bakıma, bugünkü nesillerle gelecek nesilleri dayanışma ve iş birliği temelinde birbirine bağlar. Öte yandan çevre hakkı yersel kısıtlamalara da tabi tutulamaz. Zira çevresel tahribat söz konusu olduğunda ortaya çkan olumsuzlukların idari sınırlarla belirlenmesi mümkün değildir. Çevre hakkını diğer insan haklarından ayıran en belirgin özelliklerden bir tanesi de haködev diyalektiği bağlamında kendini gösterir ${ }^{10}$. Çevre hakkından yararlananlar aynı zamanda bu hakkın muhataplarıdır. Çevre hakkı söz konusu olduğunda hak sahipleri aynı zamanda çevrenin korunması ödevini de yerine getirmekle yükümlüdürler ${ }^{11}$.

\section{II. ÇEVRE HAKKINA İLİ̧̧KIN TÜRK HUKUKUNDA YER ALAN BAŞLICA DÜZENLEMELER}

Çevre hakkı, 1982 Anayasası'nın "Sağlık Hizmetleri ve Çevrenin Korunması" başlıklı 56. maddesinde düzenlenmiştir. Anayasanın, "Sosyal ve Ekonomik Haklar ve Ödevler” bölümünde yer alan 56. maddesinin çevreyle ilgili ilk fıkrasına göre; "Herkes, sağlıklı ve dengeli bir çevrede yaşama hakkına sahiptir.

\footnotetext{
Kaboğlu, İbrahim (1996) Çevre Hakkı, İmge Kitabevi Yayınları, s. 11.

Kaboğlu (1996), s. 12; Memiş, Emin (2015) Çevre ve Çevre İdare Hukuku, Filiz Kitabevi, s. 351-352.

Turgut, s. 164-167.

Turgut, s. 139.

Yokuş Sevük, Handan (2017) Çevre Hukuku, 2. Baskı, Adalet Yayınevi, s. 22; Kaplan, Mahmut (2018) İmar Kirliliğine Neden Olma Suçu, Ankara, Seçkin Yayınları, s. 55.
} 
Çevreyi geliştirmek, çevre sağlı̆̆ını korumak ve çevre kirlenmesini önlemek devletin ve vatandaşların ödevidir”. Bu düzenlemeden görüldüğü üzere, Anayasamız herkesin sağlıklı ve dengeli bir çevrede yaşama hakkına sahip olduğunu öngörmek suretiyle çevre hakkını güvence altına almıştır.

1982 Anayasası'nın çevre hakkı ile ilgili temel normu 56. maddede yer alan düzenleme olmakla birlikte, bazı başka maddelerde de çevreyle ilgili düzenlemelere rastlamak mümkündür. 44. maddede toprağın korunmasına ve geliştirilmesine, 63. maddede tarih, kültür ve tabiat varlıklarının korunmasına ve değerlendirilmesine, 166. maddede ülke kaynaklarının verimli kullanılmasına, 168. maddede doğal zenginliklerin ve kaynakların devletin hüküm ve tasarrufu altında olduğuna ve 169. maddede ormanların korunması ve geliştirilmesine ilişkin hükümler yer almaktadır.

1982 Anayasası'nın 65. maddesi, Anayasa'da Sosyal ve Ekonomik haklar başlığı altında düzenlenen hakların uygulanma olanağını kısıtlar. 65. maddede yer alan düzenlemeye göre, "Devlet, sosyal ve ekonomik alanlarda Anayasa ile belirlenen görevlerini, bu görevlerin amaçlarına uygun öncelikleri gözeterek mali kaynaklarının yeterliliği ölçüsünde yerine getirir”. Bu bağlamda, çevre hakkının Anayasa'da Sosyal ve Ekonomik haklar başlığı altında düzenlenmesinin, 56. maddenin uygulanma olană̆ının kısıtlanması sonucunu doğurduğu söylenebilir. Öte yandan öğretide de haklı olarak belirtildiği gibi, 56. maddede yalnızca çevre hakkından değil, "sağlıklı ve dengeli bir çevrede yaşama hakkı"ndan bahsedilmektedir. Dolayısıyla burada yer alan "sağlıklı ve dengeli bir çevre ifadesini”, klasik temel haklardan olan yaşam hakkı ile birlikte yorumlayarak söz konusu kısıtlamanın aşılması mümkün gözükmektedir ${ }^{12}$.

2872 sayılı Çevre Kanunu'nun 3. maddesinin (e) bendinde de “çevre hakkından" bahsedilmektedir ${ }^{13}$. Bu düzenlemeye göre, "Çevre politikalarının oluşmasında katılım hakkı esastır. Bakanlık ve yerel yönetimler; meslek odaları, birlikler, sivil toplum kuruluşları ve vatandaşların çevre hakkını kullanacakları katılım ortamını yaratmakla yükümlüdür”.

\footnotetext{
12 Turgut, s. 139.

13 http://www.mevzuat.gov.tr/MevzuatMetin/1.5.2872.pdf Erişim Tarihi: 12.03.2019.
} 


\section{AVRUPA İNSAN HAKLARI SÖZLEŞMESİNDE ÇEVRE HAKKI}

Çevre hakkı, Avrupa İnsan Hakları Sözleşmesi'nde (AİHS) veya Sözleşme’ye ek protokollerde özel olarak düzenlenmiş değildir. Ancak Avrupa İnsan Hakları Mahkemesi (AİHM), çevre hukukunun gelişimine ve çevresel sorunların artmasına paralel olarak, geliştirmiş olduğu içtihatlarla, Sözleşmenin çevre hakkının gelişimi ve çevrenin korunması açısından önemli bir hukuki araca dönüşmesini sağlamıştır ${ }^{14}$.

AİHM, çevre konusuna iki farklı açıdan yaklaşmaktadır ${ }^{15}$. İlk olarak, Mahkemeye göre çevrenin korunması, taraf devletlerin Sözleşme ile garanti altına alınan bazı haklar bakımından öngördüğü sınırlamaları haklı kılabilir. Çevrenin korunması amacıyla getirildiği için Mahkemece meşru kabul edilen bu sınırlamalar, özellikle mülkiyet hakkı ve özel hayatın korunması hakları bakımından söz konusu olur. Fredin v. İsveç Kararı'nda Mahkeme, çevreyi koruma amacıyla çıkarılan bir yasa gereği, özel bir şahsa ait kum ve çakıl ocağının faaliyetlerinin durdurulmasını, Sözleşmeye ek 1 No'lu Protokolün 1. maddesinde düzenlenen mülkiyet hakkının ihlali olarak görmemiştir ${ }^{16}$.

AİHM'in çevrenin korunmasına asıl katkısı, Sözleşmede yer alan bazı hakların çevre hakkı ile birlikte yorumlanması suretiyle gerçekleşmektedir ${ }^{17}$. Bu bağlamda AİHM tarafından en sık başvurulan hak, Sözleşmenin 8. maddesinde düzenlenen özel hayat ve aile hayatının korunması hakkıdır. Mahkeme özellikle, sanayi atıklarından veya çöp istasyonlarından kaynaklanan kirlilik ve gürültü ve ses kirliliğini kişinin özel hayatı ve aile hayatını ihlal eden bir müdahale olarak nitelendirilmektedir. Ostra v. İspanya Kararı'nda Mahkeme, çevre kirliliğinin, kişilerin sağlığını tehlikeye atmasa bile, esenliklerini olumsuz olarak etkileyebileceğini ve bunun da 8 . maddenin ihlali olarak değerlendirilmesi gerektiğini ifade etmiştir ${ }^{18}$. Bir başka deyişle AİHM, 8. maddenin uygulanabilmesi

\footnotetext{
14 Duymaz, Erkan (2012) “Avrupa İnsan Hakları Mahkemesi'nin Çevrenin Korunmasına Katkısı”, İstanbul Üniversitesi Siyasal Bilgiler Fakültesi Dergisi, S: 47, s. 123. Harris, D.J/O’Boyle, M/Bates, E.P/Buckley, C.M (2013) Avrupa İnsan Hakları Sözleşmesi Hukuku, 1. Baskı, Avrupa Konseyi, s. 397.

15 Duymaz, s. 125.

16 Fredin v. İsveç, Başvuru No: 12033/86, 18.02.1991. https://hudoc.echr.coe.int/ Erişim: 19.02.2019.

17 Mowbray, Alistar (2007), Cases and Materials on the European Convention on Human Rights, 2. Baskı, Oxford University Press, s. 546-552; Güneş (2014), s. 88.

18 Güneș (2014), s. 89.
} 
için başvuranların gündelik hayatları bakımından ağır bir tehlike halinin varlığını aramamakta, başvuranların sağlığı, özel hayat ve aile hayatı bakımından ciddi bir tehlike oluşturabilecek ağır çevresel ihlallerin varlığı bu maddenin uygulanması bakımından yeterli görülmektedir. Benzer şekilde, Guerra ve Diğerleri v. İtalya ${ }^{19}$, Giocornelli v. İtalya ${ }^{20}$, Fadeyeva v. Rusya ${ }^{21}$, Tatar v. Romanya ${ }^{22}$, Dubetska ve Diğerleri v. Ukrayna ${ }^{23}$, ve Apanesewicz v. Polonya ${ }^{24}$ Kararlarında da endüstriyel kirliliğin özel hayatın ve aile hayatının korunması hakkını ihlal ettiği hüküm altına alınmıştır. Endüstriyel kirliliğgin konu edildiği bu kararların ortak özelliği, başvuranların devletin bu hakka mündemiç olan yasadışı faaliyetlerin kontrol altına alınması, bu faaliyetlerin sorumlularının ortaya çıkarılması veya sorumlulara karşı herhangi bir yaptırım uygulanmaması gibi yükümlülüklerin ihlali suretiyle ciddi bir kirliliğe maruz bırakılmış olmalarıdır. Öte yandan Sözleşmede temiz ve sessiz bir çevrede yaşama hakkı şeklinde bir hak güvence altına alınmadığı için, özel hayat çerçevesinde korunan hukuksal çıkarlar üzerinde doğrudan ve ciddi bir etkisi bulunmayan, manzara hakkı veya güzel bir çevrede yaşama hakkı gibi çevresel hakların Sözleşme'nin 8. maddesi kapsamında değerlendirilmesi söz konusu değildir ${ }^{25}$.

AİHM’ne göre, gürültü kirliliği de AİHS’nin 8. maddesinin kapsamında bir müdahale olarak değerlendirilebilir. Mahkeme konuya ilişkin olarak Powell ve Rayner v. Birleşik Krallık Kararında ${ }^{26}$, uçaklardan kaynaklanan gürültünün, havaalanı yakınlarında oturanların yaşam kalitesini düşürdüğü gerekçesiyle, söz konusu durumu başvuranların özel hayat ve aile hayatlarına yönelik bir müdahale olarak değerlendirmiştir. Mahkeme tarafından benzer bir saptama Hatton ve Diğerleri v. Birleşik Krallık ${ }^{27}$ ve Moreno Gomez v. İspanya ${ }^{28}$ Kararlarında

19 Guerra ve Diğerleri v. İtalya, Başvuru No: 116/1996/735/932, 19.02.1998. https://hudoc.echr.coe.int/ Erişim:19.02.2019.

20 Giocornelli v. İtalya, Başvuru No: 59909/00, 26.03.2007. https://hudoc.echr.coe.int/ Erişim: 21.02.2019.

${ }^{21}$ Fadeyeva v. Rusya, Başvuru No: 55723/00, 09.06.2005. https://hudoc.echr.coe.int/ Erișim: 20.02.2019.

22 Tatar v. Romanya, Başvuru No: 67021/01, 06.07.2009. https://hudoc.echr.coe.int/ Erişim: 21.02.2019.

23 Dubetska ve Diğerleri v. Ukrayna, Başvuru No: 30499/03, 10.05.2011. https://hudoc.echr.coe.int/ Erişim: 20.02.2019.

24 Apanesewicz v. Polonya, Başvuru No: 6854/07, 03.05.2011. https://hudoc.echr.coe.int/ Erişim:19.02.2019.

25 Krytatos v. Yunanistan, Başvuru No: 41666/98, 22.5.2003. https://hudoc.echr.coe.int/ Erişim: 21.02.2019.

26 Powell ve Rayner v. Birleşik Krallık, Başvuru No: 9310/81, 21.02.1990. https://hudoc.echr.coe.int/ Erişim: 19.02.2019.

27 Hatton ve Diğerleri v. Birleşik Krallık, Başvuru No: 36022/97, 08.07.2003. https://hudoc.echr.coe.int/ Erişim: 16.02.2019.

28 Moreno Gomez v. İspanya, Başvuru No: 4143/02, 16.11.2004. https://hudoc.echr.coe.int/ Erişim: 21.02.2019. 
da yapılmıştır. Hatton ve Diğerleri v. Birleşik Krallık Kararında yine uçaklardan kaynaklanan gürültü nedeniyle ihlal kararı verilirken, Moreno Gomez v. İspanya Kararında ise yerel makamların ulusal mevzuata aykırı olarak gürültü kirliliğine neden olan bar ve diskoteklere işletme izni vermesi nedeniyle, başvuranların konut haklarının ihlal edildiği sonucuna varılmıştır.

AİHM’nin çevre hakkı ile bağlantılı olarak değerlendirdiği bir diğer hak AİHS'nin 2. maddesinde düzenlenen yaşam hakkıdır. Mahkeme'ye göre yaşam hakkı, taraf devletleri, kişiyi yaşamından mahrum etmeme yükümlülüğünün yanı sıra kişilerin yaşamlarının korunması için gerekli pozitif edimlerde bulunma yükümlülüğü altına da sokar. Bu bağlamda, devletler çevresel felaketlerin neden olabileceği riskleri ortadan kaldırmak için gerekli tedbirleri almakla yükümlüdür ve bu risklerin gerçekleşmesi neticesinde meydana gelen ölüm olayları AİHM tarafından yaşam hakkına yönelik bir müdahale olarak değerlendirilir. Mahkeme Öneryıldız v. Türkiye Kararında ${ }^{29}$, çöp istasyonunda gerçekleşen metan gazı patlaması sonucunda yakınlarını ve evini kaybeden bir kişinin yaptığı başvuruyu kabul ederek, Türkiye'nin Sözleşme'nin 2. maddesini ihlal ettiğini saptamıştır. Mahkeme'ye göre, somut olayda kamusal makamların patlama tehlikesinin varlığını öngören raporların varlığına rağmen gerekli tedbirleri almaması, patlamanın nedenlerinin ve sorumluların etkili bir şekilde soruşturulmaması devletin yaşam hakkının korunması bağlamında üzerine düşen pozitif edim yükümlülüğünün gereği gibi yerine getirilmediği anlamına gelmekte olup, yaşam hakkının ihlali sonucunu doğurur ${ }^{30}$.

AİHS'nin 6. maddesinde düzenlenen adil yargılanma hakkı da çevre ile ilgili davalarda çevre hakkı ile birlikte gündeme gelen haklardandır. Adil yargılanma hakkı, bireyin kendiliğinden kullandığı, esasa ilişkin haklardan farklı olarak, uyuşmazlıkların hakkaniyete uygun bir biçimde çözülebilmesi için oluşturulan adalet mekanizması önünde kullanılabilecek, usule ilişkin birtakım güvenceler getirir. Sözleşmede yer alan düzenlemeye göre, "Herkes, gerek medeni hak ve yükümlülükleriyle ilgili uyuşmazliklar, gerek cezai alanda kendisine yöneltilen suçlamalar konusunda karar verecek olan, yasayla kurulmuş, bağımsız ve tarafsız bir mahkeme tarafindan davasının makul bir süre içinde, hakkaniyete uygun ve açık olarak görülmesini isteme hakkına sahiptir”. AİHM, sağlıklı ve

Öneryıldız v. Türkiye, Başvuru No: 48939/99, 30.11.2004. https://hudoc.echr.coe.int/ Erişim: 18.02.2019.

Öneryıldız v. Türkiye, Başvuru No: 48939/99, 30.11.2004. https://hudoc.echr.coe.int/ Erişim: 18.02.2019. 
dengeli bir çevrede yaşama hakkının da 6. madde ile korunan medeni haklardan olduğunu kabul etmektedir ${ }^{31}$. Mahkemeye göre, usulüne uygun olarak verilmiş mahkeme kararlarına idare tarafından uyulmaması $1^{32}$, alınan idari kararlara karşı yargı yolunun kapalı olması ${ }^{33}$ gibi durumlarda 6 . madde ile güvence altına alınmış olan adil yargılanma hakkı ihlal edilmiş olur.

Çevresel sorunlarla ilgili olarak önem arz eden bir diğer hak, AİHS'nin 1 No'lu ek protokolünün 1. maddesinde güvence altına alınmış olan mülkiyet hakkıdır. Yukarıda da ifade ettiğimiz gibi AİHM, çevrenin korunmasını kamu yararının haklı gereklerinden biri olarak kabul etmekte ve mülkiyet hakkı gibi bazı hakların çevrenin korunması gerekçesiyle sınırlanabileceğini düşünmektedir. Öte yandan sınırlı ve dolaylı bir biçimde de olsa, Mahkeme tarafından bazı durumlarda çevre hakkının ihlali, mülkiyet hakkının ihlali ile birlikte değerlendirilmiştir. Bu duruma ilişkin yine Öneryıldız v. Türkiye Kararı örnek olarak gösterilebilir. İlgili kararda Mahkeme, çöplükte gerçekleşen patlamada her ne kadar evini kaçak olarak inşa etmiş olsa da, evini ve eşyalarını kaybeden başvuranın, bu duruma devlet tarafından göz yumulmuş olduğundan, mülkiyet hakkının ihlal edildiğine karar vermiştir ${ }^{34}$.

\section{BİREYSEL BAŞVURUYA İLİŞKİN GENEL AÇIKLAMALAR}

Bireysel başvuru, temel hak ve hürriyetleri, kamu gücünün işlem, eylem veya ihmalleri nedeniyle ihlal edilen bireylerin, olağan kanun yollarını tükettikten sonra başvurdukları istisnai ve ikincil nitelikte bir hak arama yoludur ${ }^{35}$.

Anayasa şikâyeti olarak da adlandırılan bireysel başvuru, anayasa yarg1sının, temel hak ve hürriyetlerin korunması ve anayasal düzenin sağlanması işlevlerinin yerine getirilmesine hizmet eder ${ }^{36}$.

\section{Güneș (2014), s. 92.}

32 Taşkın ve Diğerleri v. Türkiye, Başvuru No: 46117/99, 10.11.2004; Okyay ve Diğerleri v. Türkiye, Başvuru No: 36220/97, 12.07.2005; Öçkan ve Diğerleri v. Türkiye, Başvuru No: 46771/99, 28.03.2006. https://hudoc.echr.coe.int/ Erișim: 18.02.2019.

33 Zander v. İsveç, Başvuru No: 14282/88, 25.11.1993. https://hudoc.echr.coe.int/ Erişim: 18.02.2019.

34 Öneryıldız v. Türkiye, Başvuru No: 489/39, 30.11.2004. https://hudoc.echr.coe.int/ Erișim: 18.02.2019.

35 Ekinci, Hüseyin/Sağlam, Musa (2012) 66 Soruda Anayasa Mahkemesi'ne Bireysel Başvuru, Ankara, s. 9; Tanör, Bülent/Yüzbaşıŏlu, Necmi (2018) 18. Baskı, İstanbul, Beta, s. 558.

36 Göztepe, Ece (1998) Anayasa Şikâyeti, Ankara, Ankara Üniversitesi Hukuk Fakültesi Yayınları No: 530, s. 17; Kaboğlu, İbrahim (2007) Anayasa Yargısı, 4. Baskı, Ankara, s. 169; Aydın, Öykü Didem (2011) 
Bireysel başvuru, Türk Anayasa Yargısı sistemine 12 Eylül 2010 tarihli halk oylamasıyla onaylanan 5982 sayılı Kanunla getirilmiştir. Anayasanın 148. maddesinin ilgili Kanunla değiştirilen şekliyle 3. fikrasında, "Herkes, Anayasada güvence altına alınmış temel hak ve özgürlüklerinden, Avrupa İnsan Hakları Sözleşmesi kapsamındaki herhangi birinin kamu gücü tarafından ihlal edildiği iddiasıyla Anayasa Mahkemesine başvurabilir. Başvuruda bulunabilmek için olağan kanun yollarının tüketilmiş olması şarttır." hükmüne yer verilmiştir.

$\mathrm{Bu}$ düzenlemeden hareketle, Anayasa Mahkemesine bireysel başvuru yolu ile başvurulabilmesi için, başvuruda bulunacak kişinin Anayasa ve AİHS tarafından güvence altına alınan bir temel hak ve hürriyetinin ihlal edilmiş olması gerektiği söylenebilir. Anayasa ve AİHS’nde güvence altına alınmış olma şartı birlikte gerçekleşmek zorunda olduğundan, Anayasada düzenlemiş olmakla birlikte AİHS'de tanınmayan bir hak ve hürriyetin ihlali iddiasıyla bireysel başvuru yoluna gidilemez ${ }^{37}$. AİHS tarafından güvence altına alınan hak ve hürriyetlerin kapsamına AİHS'nin esas metninde yer alanların yanı sıra Türkiye'nin taraf olduğu protokoller kapsamındaki hak ve hürriyetler de girmektedir.

Anayasa'nın 148. maddesinin 3. fikrasında yer alan düzenlemeden yola çıkarak yapılabilecek bir diğer tespit, bireysel başvuruya yalnızca devletin üç temel erki olan yasama, yürütme ve yargıya isnat edilen eylem, işlem ve ihmaller nedeniyle gerçekleşen ihlallerin konu edilebileceğidir. Kamu gücünün ihmalinin bir hak ihlali olarak değerlendirilebilmesi, kamu organlarının bir işlemde bulunma zorunluluğunun varlığına bağlıdır. Yasama işlemleri ile düzenleyici idari işlemler aleyhine doğrudan bireysel başvuru yapılamayacağı gibi Anayasa Mahkemesi kararları ile Anayasanın yargı denetimi dışında bıraktığı işlemler de bireysel başvurunun konusu olamaz (6216 sayılı Kanun m. 45/3).

Bireysel başvuruda bulunabilmek için olağan kanun yollarının tüketilmiş olması da şarttır. Bir başka deyişle, bireysel başvuruda bulunacak kişinin, bireysel başvurudan önce, hakkını diğer yargı organlarının önünde aramış olması

“Türk Anayasa Yargısında Yeni Bir Mekanizma: Anayasa Mahkemesine Bireysel Başvuru, Gazi Üniversitesi Hukuk Fakültesi Dergisi, S: 4, s. 126.

37 Gözler, Kemal (2018) Türk Anayasa Hukuku Dersleri, 22. Baskı, Bursa, Ekin Yayınevi, s. 448. 
gerekir. Yani kişi, ilk derece mahkemesinde dava açmış, kaybettikten sonra itiraz, istinaf veya temyiz gibi olağan kanun yollarına başvurmuş ve bu yolları da tüketmiş olmalıdır ${ }^{38}$. Bireysel başvuru ancak ihlale yol açtığı ileri sürülen eylem, işlem veya ihmal nedeniyle güncel ve kişisel bir hakkı doğrudan ihlal edilenler tarafından açılabilir (6216 sayılı Kanun m. 46/1). Kamu tüzel kişileri bireysel başvuru yapamaz. Özel hukuk tüzel kişileri sadece tüzel kişiliğe ait haklarının ihlal edildiği gerekçesiyle bireysel başvuruda bulunabilir (6216 sayılı Kanun m. $46 / 2)$.

Anayasa Mahkemesi, Anayasa'nın 148. maddesinin 4. fikrasında yer alan düzenleme gereğince kanun yolunda gözetilmesi gereken hususlarda inceleme yapmaz. Bir mahkeme kararına karşı yapılan bireysel başvuruya ilişkin inceleme, bir temel hakkın ihlal edilip edilmediği ve bu ihlalin nasıl ortadan kald1rrlacağının belirlenmesi ile sınırlıdır (6216 sayılı Kanun m. 49/6). Bir ihlalin tespit edildiği hallerde, Anayasa Mahkemesi'nin ihlalin ve sonuçlarının ortadan kaldırılması için yapılması gerekenlere de hükmetmesi gerekir. Bu durumda Anayasa Mahkemesi, yeniden yargılama yapılmasına karar verebileceği gibi yeniden yargılama yapılmasında hukuki yarar bulunmuyorsa başvuran lehine uygun bir tazminata da hükmedebilir.

\section{TÜRK ANAYASA MAHKEMESI'NINN BİREYSEL BAŞVURU KARARLARINDA ÇEVRE HAKKI}

Anayasanın 148. maddesi uyarınca Anayasa Mahkemesine bireysel başvuruda bulunulabilmesi için, kişinin hem Anayasa hem de AİHS tarafından birlikte güvence altına alınan bir temel hak ve hürriyetinin ihlal edilmiş olması gerektiğini yukarıda ifade etmiştik. Bu bakımdan Anayasa ile AİHS metinlerini karşılaştırarak her iki hukuki metinde ortak bir biçimde yer alan temel hak ve hürriyetleri tespit etmek suretiyle bireysel başvuruya konu edilebilecek temel hak ve hürriyetleri belirlemek mümkündür ${ }^{39}$. Öte yandan yine yukarıda ifade ettiğimiz gibi, AİHM kimi zaman Sözleşme içerisinde açıça düzenlenmemiş olan bir hakkı, Sözleşme içerisinde düzenlenen bir başka hakla birlikte değerlendirebilmekte, hakkın norm alanını içtihat yoluyla belirleyebilmektedir. $\mathrm{Bu}$

\footnotetext{
${ }^{38}$ Gözler, s. 449.

${ }^{39}$ Güneş (2014), s. 96.
} 
noktada, Anayasa Mahkemesinin bir hakkın norm alanını belirlerken AİHM’nin içtihatlarıyla bağlı olup olmadığı sorusunun yanıtlanması önem arz eder. Eğer Anayasa Mahkemesinin, yalnızca AİHS veya Sözleşmeye ek Protokoller içerisinde açıkça düzenlenmiş olan haklar açısından inceleme yapabileceği söylenirse, bu takdirde çevre hakkının korunmasına ilişkin Anayasa Mahkemesine bireysel başvuru yoluyla başvurulamayacağının da kabulü gerekir.

Anayasa Mahkemesinin bir hakkın norm alanını belirlerken AİHM'nin içtihatlarıyla bağlı olup olmadığına ilişkin Anayasa'nın konunun düzenlendiği 148. maddesinde bir açıklık bulunmamaktadır. Ancak ilgili maddenin gerekçesinde, bireysel başvuru yolunun tanınması ile AİHM'ne yapılan başvuruların bireysel başvuru kapsamında Anayasa Mahkemesi'nce karara bağlanacağı, böylelikle AİHM'ne yapılacak başvuruların azaltılacağı ifade edilmiştir. Başka bir deyişle, hukuk sistemimizde bireysel başvuru yolunun tanınmasıyla amaçlanan, Türkiye'nin ulusal hukuk normlarını bilhassa temel hak ve özgürlükler açısından AİHS standartları ile uyumlu hale getirmek ve AİHS'nin ihlal edildiğine ilişkin şikâyetleri iç hukuk kapsamında karara bağlamak suretiyle AİHM’ne yapılan başvuruları azaltmaktır. Bu amaç doğrultusunda Anayasa Mahkemesi'nin önüne gelen başvurulara ilişkin olarak AİHS ile birlikte Sözleşmeyi yorumlayan ve temel hak ve özgürlüklerle ilgili olarak asgari standartlar belirleyen AİHM içtihatlarını da dikkate alması zorunludur ${ }^{40}$. Bu nedenle, Türk hukukunda çevre hakkının bireysel başvuru yoluyla Anayasa Mahkemesi'nin önüne getirilebilmesi mümkün olduğunun kabulü gerekir. Nitekim Anayasa Mahkemesi de çevre hakkının ihlaline ilişkin önüne gelen başvuruları, başvuru şartları oluştuğu takdirde kabul edilebilir bularak, esas yönünden incelemektedir.

AİHS’nde açıkça düzenlenmemiş olan çevre hakkına ilişkin olarak Anayasa Mahkemesi'ne bireysel başvuru yoluyla başvurulabileceğini belirledikten sonra Anayasada yer alan hangi hükmün ihlali nedeniyle Anayasa Mahkemesi'ne başvurulabileceği sorusunun yanıtlanması gerekir. Bu sorunun yanıtı ilk bakışta oldukça açık görülebilir zira yukarıda da ifade ettiğimiz üzere Anayasanın 56. maddesinde açıkça "Herkes, sağlıklı ve dengeli bir çevrede yaşama hakkına sahiptir" denmek suretiyle çevre hakkına yer verilmiştir. Bununla birlikte Anayasa Mahkemesi, çevre hakkının ihlaline ilişkin önüne gelen başvurularda değerlendirmelerini 56. madde kapsamında değil, Anayasanın 17. maddesinde yer alan "maddi ve manevi varlığın korunması ve geliştirilmesi” hakkı,

\footnotetext{
${ }^{40}$ Şirin, Tolga (2013) Türkiye'de Anayasa Şikâyeti (Bireysel Başvuru), İstanbul, Oniki Levha Yayınları, s. 429.
} 
“özel hayat kavramına dahil bir kısım hukuksal değerlerin” düzenlendiği 20. madde, özel yaşamın diğer alt kategorileri olarak ele alınan "konuta dokunulmazlı̆̆g" ve "haberleşmenin hürriyetinin" düzenlendiği 21. ve 22. maddelerine ilişkin olarak yapmaktadır ${ }^{41}$. Bir başka deyişle, Anayasa Mahkemesine göre AİHS'nin 8. maddesinde yer alan hakların karşılığı temel olarak Anayasa'nın $17,20,21$ ve 22 . maddelerinde yer alan düzenlemelerdir. Öte yandan tıpkı yukarıda da bahsi geçen bazı AİHM kararlarında görüldüğü gibi, çevre hakkının ihlali bazen özel hayatın korunması hakkı dışında başka bazı hakların ihlali ile birlikte de söz konusu olabilir. Bunun örneklerine Anayasa Mahkemesi kararlarında da rastlanması mümkündür. Hidroelektrik santrali projesiyle ilgili idarece verilen "Çevresel Etki Değerlendirmesi gerekli değildir” kararının iptalinin istemiyle açılan davanın reddi nedeniyle Anayasanın 2, 17. ve 56. maddelerinde düzenlenen hakların ihlal edildiği gerekçesiyle yapılan başvuru, Anayasa Mahkemesi tarafından 36. maddede düzenlenen adil yargılanma hakkı kapsamında incelenmiş ve ihlal kararı verilmiştir ${ }^{42}$.

Anayasa Mahkemesi, çevre hakkına ilişkin vermiş olduğu çeşitli kararlarında Anayasa'nın 56. maddesi yerine neden 17. madde bakımından bir değerlendirme yapmış olduğu hususuna da açıklık getirmiştir. Mahkemeye göre, Anayasa'da "Herkes, Anayasada güvence altına alınmış temel hak ve özgürlüklerinden, Avrupa İnsan Hakları Sözleşmesi kapsamındaki herhangi birinin kamu gücü tarafindan, ihlal edildiği iddiasıyla Anayasa Mahkemesine başvurabilir." hükmüne yer verilmiş olması, Anayasa' da yer alan ikinci ve üçüncü kuşak hakların ihlal edildiği iddiasıyla bireysel başvuruda bulunulamayacağı şeklinde yorumlanmalıdır ${ }^{43}$. Gerçekten de AİHS'de kural olarak kişisel ve siyasal haklar düzenlenmiştir.

Yine, farklı ülkelerdeki uygulamalar genellikle birinci kuşak hakların yani kişisel ve siyasal hakların bireysel başvuruya konu edilebileceği yönündedir. Dolayısıyla Anayasa Mahkemesi’nin, sağlıklı bir çevrede yaşama hakkına Anayasa'nın “Sosyal ve Ekonomik Haklar” bölümünde yer verilmiş olmasından

${ }^{41}$ Hüseyin Tunç Karlık ve Zahide Şadan Karluk, Başvuru No: 2013/6587, 24.3.2016, para. 41; Binali Özkaradeniz ve Diğerleri, Başvuru No: 2014/4686, 1.2.2018, para. 45.

https://kararlarbilgibankasi.anayasa.gov.tr/ Erişim: 23.02.2019.

42 Mehmet Bolat ve Diğerleri, Başvuru No: 2013/5974, 10.03.2016.

https://kararlarbilgibankasi.anayasa.gov.tr/ Erişim: 23.02.2019.

43 Mehmet Kurt, Başvuru No: 013/2552, 25.02.2016, para. 46. https://kararlarbilgibankasi.anayasa.gov.tr/ Erişim: 23.02.2019. 
dolayı 56. madde yerine anılan maddeler bakımından bir değerlendirme yapmasının teknik olarak yerinde olduğunu söylemek mümkündür. Bununla birlikte Mahkeme, 56. maddeye kamusal makamların çevresel meseleler bağlamındaki pozitif yükümlülüklerinin tespiti ve değerlendirilmesi konusunda başvurulması gerektiğini, ilgili düzenlemenin, "Devlet, özel teşebbüslerin millî ekonominin gereklerine ve sosyal amaçlara uygun yürümesini, güvenlik ve kararlılı içinde çalışmasını sağlayacak tedbirleri alır.” şeklindeki 48. madde ile birlikte kamusal makamların çevresel meseleler bağlamındaki pozitif yükümlülüklerinin normatif dayanaklarından birini teşkil ettiğini ifade etmektedir ${ }^{44}$. Mahkeme'ye göre, Anayasa'nın 17. maddesinde düzenlenen "Maddi ve Manevi Varlığı Koruma ve Geliştirme Hakkı” ise, bireysel başvuru kapsamında Anayasa ve Sözleşme'nin ortak koruma alanında yer alan temel hak ve hürriyetlere ilişkin güvenceler yönünden dikkate alınması gereken çerçeve bir düzenleme olarak değerlendirilmelidir ${ }^{45}$.

Anayasa Mahkemesi, konuya ilişkin kendi önüne gelen başvuruları AİHM’nin uygulamasına paralel olarak iki ayrı açıdan inceler. Mahkeme'ye göre değerlendirilmesi gereken ilk husus, ilgili çevresel etkinin Anayasanın 17. maddesi kapsamındaki güvenceleri harekete geçirecek asgari ağırlıkta olup olmadığıdır. Söz konusu ağırlığın belirlenmesinde, ölçüt olarak, çevresel etkinin yoğunluğu, süresi, fiziksel ve ruhsal sonuçları dikkate alınmalıdır ${ }^{46}$. İlgili çevresel rahatsızlığın başvuranın özel ve aile yaşamı ya da konuta saygı hakkı üzerinde doğrudan bir etkide bulunması ve çevresel kirliliğin belirtilen değerler üzerindeki etkisinin asgari bir şiddet derecesine ulaşması gerekmektedir. Söz konusu şiddet derecesinin değerlendirilmesi göreceli olup her somut olayın kendi özellikleri dikkate alınır.

Çevresel kirliliğin asgari şiddet derecesine ulaşıldığı tespit edildikten sonra, değerlendirilmesi gereken ikinci husus, çevresel karar alma süreçlerine muhatap olan bireylere sağlanması gereken usule ilişkin güvencelerin sağlanıp

44 Mehmet Kurt, Başvuru No: 013/2552, 25.02.2016, para. 50-51.

https://kararlarbilgibankasi.anayasa.gov.tr/ Erişim: 23.02.2019.

45 Binali Özkaradeniz ve Diğerleri, Başvuru No: 2014/4686, 1.2.2018, para. 43.

https://kararlarbilgibankasi.anayasa.gov.tr/ Erişim: 23.02.2019.

46 Mehmet Kurt, Başvuru No: 013/2552, 25.02.2016, para. 67. https://kararlarbilgibankasi.anayasa.gov.tr/ Erişim: 23.02.2019. 
sağlanmadığıdır. Anayasa Mahkemesine göre, çevresel karar alma süreçlerine muhatap olan bireylere sağlanması gereken usul güvencelerinin en önemli unsurlarından biri, kamusal makamların eylem veya ihmallerini bağımsız yargısal bir makam önüne taşıma ve gerektiği şekilde inceletebilme imkânıdır. Bununla birlikte, bu makamlara başvuru imkânının sunulması tek başına usule ilişkin güvencelerin sağlandığı anlamına gelmez. İlgili kamusal makamların konuya gereken özenle yaklaşmaları, tüm menfaatleri gözeterek bir denge tesis etmeleri, bunun için de bireylerin sürece etkin katılımı sağlanarak tüm itiraz ve delillerini sunma, inceletme ve esasa etkili tüm iddialarının gerekçeleriyle karş1lanması olanağını elde etmeleri de $\operatorname{aran}^{4}{ }^{47}$. Hak ihlalinin varlığına ilişkin iddiaların ilk derece mahkemeleri tarafından, başvuranların, kamusal makamların ve kamunun menfaatleri arasında adil bir denge gözetilmek suretiyle çözüme kavuşturulması zorunludur. Mahkeme Kurt Kararı'nda, "başvuranın temel iddialarına doğrudan bir cevap verilmemesini ve çevresel rahatsızlı̆̆na ilişkin iddialarının yargı mercileri önünde gerektiği gibi değerlendirilmesi imkânını elde edememesini" maddi ve manevi varlığın korunması ve geliştirilmesi hakkının korunması ve etkin kullanımının sağlanması bağlamında kamusal makamların pozitif yükümlülüklerinin yerine getirilmemesi olarak değerlendirmiştir ${ }^{48}$.

\section{SONUÇ}

Çevre hakkı, asıl öznesi çevrenin kendisi olan, ancak bu hak yoluyla sağlanacak korumanın insanların sahip olduğu sağlıklı bir çevrede yaşam hakkı vasıtasıyla gerçekleştirilebileceği genel kabulünden dolayı, ulusal ve uluslararası belgelerde bir insan hakkı olarak düzenlenmiş bulunan bir temel haktır. AİHS'nde ayrıca ve açıkça düzenlenmemiş olan çevre hakkı, AİHM tarafından Sözleşmede yer alan bazı hak ve hürriyetler, özellikle de Sözleşmenin 8. maddesinde güvence altına alınan özel hayatın, aile hayatının ve konutun korunması hakkı ile birlikte değerlendirilmektedir. Bir hakkın AİHS veya Sözleşmeye ek protokollerde açıkça düzenlenmiş olması iç hukukumuz bakımından ilgili hakkın ihlalinden dolayı bireysel başvuru yoluyla Anayasa Mahkemesi'ne gidilip

\footnotetext{
47 Mehmet Kurt, Başvuru No: 013/2552, 25.02.2016, para. 81. https://kararlarbilgibankasi.anayasa.gov.tr/ Erişim: 23.02.2019.

48 Mehmet Kurt, Başvuru No: 013/2552, 25.02.2016, para. 82-83.
} 
gidilememesi bakımından önemlidir. Zira Anayasanın 148. maddesinde yer alan düzenlemeye göre, bir temel hakkın ihlalinden dolayı Anayasa Mahkemesine bireysel başvuru yoluyla başvurulabilmesi için hakkın Anayasa ve AİHS'de birlikte düzenlenmiş olma şartı vardır. Bununla birlikte, iç hukukumuza bireysel başvuru yolunun kazandırılmış olmasının altında yatan amaç göz önünde bulundurulduğunda, Sözleşmede açıkça düzenlenmemiş olsa dahi, içtihat yoluyla güvence altına alınan haklar bakımından da bireysel başvuru yoluyla Anayasa Mahkemesine başvurunun mümkün olduğunun kabulü gerekir. Bir başka deyişle Anayasa'nın 56. maddesinde düzenlenen sağlıklı bir çevrede yaşama hakkının ihlali nedeniyle bireysel başvuru yolu ile Anayasa Mahkemesine başvuru mümkündür.

Anayasa Mahkemesi de çevre hakkının ihlali nedeniyle yapılan bireysel başvuruları esastan incelemektedir. Ancak Mahkeme, bu incelemeyi 56. maddede düzenlenen "sağlıklı bir çevrede yaşama hakkı" yönünden değil, 17. maddede düzenlenmiş bulunan "maddi ve manevi varlığın geliştirilmesi hakkı" bakımından yapmaktadır. Buna gerekçe olarak sağlıklı bir çevrede yaşama hakkının ekonomik ve sosyal haklar arasında düzenlenmiş olmasını gösteren Anayasa Mahkemesi, bireyin sağlıklı bir çevrede yaşamasını maddi ve manevi varlığını geliştirebilmesi hakkının bir unsuru olarak kabul etmektedir.

Bireyin maddi ve manevi varlığını geliştirmesi ve gerçekleştirmesi kavramı, AİHM tarafından esas olarak özel hayata saygı hakkının kapsamının belirlenmesinde temel alınan bir kavramdır ${ }^{49}$. Mahkeme, konuya ilişkin önüne gelen başvurularda, çevresel kirliliğin, özel hayatın veya aile hayatının nitelik ve kalitesini veya konutu keyif alarak kullanma şeklindeki hukuksal çıkarı olumsuz etkilediğini tespit ederek özel hayat kavramının alt kategorileri olan özel hayat, aile hayatı ve konuta saygı hakkı ile sağlıklı bir çevrede yaşama hakkı arasında bir bağ kurmaktadır. Aynı doğrultuda Anayasa Mahkemesi de özel hayat kavramına dâhil bir kısım hukuksal değerin Anayasa'nın 20. maddesinde düzenlendiği, özel yaşamın diğer alt kategorileri olarak ele alınan haberleşmenin gizliliği ve konuta saygı hakkının ise Anayasa'nın 21. ve 22. maddelerinde

49 Koch v. Almanya, Başvuru No: 497/09, 19.7.2012, para. 51. https://hudoc.echr.coe.int/ Erişim: 18.02.2019. 
güvence altına alındığını belirtmekte ve 17. madde ile birlikte bu maddelere de göndermede bulunmaktadır.

Anayasa Mahkemesi'nin çevre hakkının ihlali nedeniyle yapılan bireysel başvuruları "sağlıklı bir çevrede yaşama hakkı" yönünden değil, "maddi ve manevi varlığın geliştirilmesi” ve "özel hayatın korunması" hakları bakımından değerlendirmesinin temelinde bireysel başvuruya yalnızca birinci kuşak haklar olarak da ifade edilen kişisel ve siyasal hakların konu edilebileceği kabulü yatmaktadır. Oysa öğretide, insan haklarının bölünmez bir bütün olduğundan hareketle farklı hak kategorileri arasında kopmaz bir bağın olduğu, farklı kategorilerde yer alan hakları birbirlerinden soyutlayarak ele almanın bu hakların işlevsiz kılınması sonucunu doğuracağı anlayışı hakimdir ${ }^{50}$. Bu bağlamda biz de çevre hakkının Anayasa'nın 56. maddesinde düzenlenen "sağlıklı bir çevrede yaşama hakkı" yönünden yapılmasının çevrenin korunması bakımından daha etkili sonuçlara ulaşılmasını sağlayacağı kanaatindeyiz. Zira ilgili mahkeme kararlarında da bahsi geçtiği üzere, özel hayata saygı hakkı kapsamında çevre tek başına korunması gereken bir değer olarak kabul görmemekte, çevresel kirliliğin bireyin özel veya aile hayatını doğrudan etkilemesi ve belirli bir katlanma düzeyini geçmesi halinde özel hayata saygı hakkı bakımından bir sorunun mevcut olduğu kabul edilmektedir ${ }^{51}$. Bir başka deyişle, Anayasa Mahkemesinin çevre hakkının korunması ile ilgili olarak AİHM kararları paralelinde ortaya koyduğu içtihadını, bireysel başvuru yoluna yalnızca kişisel ve siyasal haklarla ilgili olarak başvurulabilir şeklindeki kabulü terk ederek Anayasanın 56. maddesini de dahil etmek suretiyle geliştirmesi ve bu suretle çevrenin korunmasına daha fazla katkıda bulunması mümkün gözükmektedir.

50 Kapani, Münci (1993) Kamu Hürriyetleri, 7. Baskı, Ankara, Yetkin Yayınları, s. 6-7.

51 D. Ö. Başvurusu, Başvuru No: 2014/3735, 12.06.2018, para. 38.

https://kararlarbilgibankasi.anayasa.gov.tr/ Erişim: 23.02.2019. 


\section{KAYNAKÇA}

Aydın, Öykü Didem (2011) "Türk Anayasa Yargısında Yeni Bir Mekanizma: Anayasa Mahkemesine Bireysel Başvuru, Gazi Üniversitesi Hukuk Fakültesi Dergisi, S: 4, s. 121-170.

Aygörmez Uğurlubay, Gülsün (2015) Çevreye Karşı Suçlar Türk ve Alman Hukukunda Güncel Sorunlar, Yetkin Yayınları.

Duymaz, Erkan (2012) “Avrupa İnsan Hakları Mahkemesi’nin Çevrenin Korunmasına Katkısı”, İstanbul Üniversitesi Siyasal Bilgiler Fakültesi Dergisi, S: 47, s. 121-160.

Ertaş, Şeref (2012) Çevre Hukuku ve Hayvan Hakları Hukuku, İleri Yayınevi.

Gözler, Kemal (2018) Türk Anayasa Hukuku Dersleri, 22. Baskı, Bursa, Ekin Yayınevi.

Göztepe, Ece (1998), Anayasa Şikâyeti, Ankara, Ankara Üniversitesi Hukuk Fakültesi Yayınları No: 530.

Güneş, Ahmet (2009) "Alman Çevre Hukukunun Anayasal Çerçevesi”, Ankara Üniversitesi Hukuk Fakültesi Dergisi, C: 58, S: 4, s. 777-821.

Güneş, Ahmet (2014) "Çevre Hakkının Bireysel Başvuruya Konu Edilebilirliği Üzerine”, TAAD, Y1l: 5, S: 16, s. 79-103.

Harris, D.J/O’Boyle, M/Bates, E.P/Buckley, C.M (2013), Avrupa İnsan Hakları Sözleşmesi Hukuku, 1. Baskı, Avrupa Konseyi,

Kaboğlu, İbrahim (1996) Çevre Hakkı, İmge Kitabevi Yayınları.

Kaboğlu, İbrahim (2007) Anayasa Yargısı, 4. Baskı, Ankara, İmge Kitabevi Yayınları.

Kapani, Münci (1993) Kamu Hürriyetleri, 7. Baskı, Ankara, Yetkin Yayınları.

Kaplan, Mahmut (2018) İmar Kirliliğine Neden Olma Suçu, Ankara, Seçkin Yayınları.

Leib Hajjar, Linda (2011) Human Rights and the Environment, Martinus Nijhoff Publishers. 
Memiş, Emin (2015) Çevre ve Çevre İdare Hukuku, Filiz Kitabevi.

Mowbray, Alistar (2007) Cases and Materials on the European Convention on Human Rights, 2. Baskı, Oxford University Press,

Özdek, Yasemin (1993) İnsan Hakkı Olarak Çevre Hakkı, Ankara, Türkiye ve Orta Doğu Amme İdaresi Enstitüsü Yayınları No: 249.

Shelton, Dinah (1991) "The Right to Environment": Eide, Asborn/Helgesen, Jan, The Future of Human Rights Protection in a Changing World, Oslo, Norwegian University Press.

Şirin, Tolga (2013) Türkiye'de Anayasa Şikayeti (Bireysel Başvuru), İstanbul, Oniki Levha Yayınları.

Tanör, Bülent/Yüzbaşığlu, Necmi (2018) 18. Baskı, İstanbul, Beta Yayınlar1.

Turgut, Nükhet (2001) Çevre Hukuku, Ankara, Savaş Yayınevi.

Yokuş Sevük, Handan (2017) Çevre Hukuku, 2. Baskı, Adalet Yayınevi.

\section{ÇALIŞMA İÇERİSINNDE GEÇEN MAHKEME KARARLARI Avrupa İnsan Hakları Mahkemesi Kararları}

Apanasewicz v. Polonya, Başvuru No: 6854/07, 03.05.2011.

Dubetska ve Diğerleri v. Ukrayna, Başvuru No: 30499/03, 10.05.2011.

Fadeyeva v. Rusya, Başvuru No: 55723/00, 09.06.2005.

Fredin vs. İsveç, Başvuru No: 12033/86, 18.02.1991.

Giocornelli v. İtalya, Başvuru No: 59909/00, 26.03.2007.

Guerra ve Diğerleri v. İtalya, Başvuru No: 116/1996/735/932, 19.02.1998.

Hatton ve Diğerleri v. Birleşik Krallık, Başvuru No:36022/97, 08.07.2003.

Koch v. Almanya, Başvuru No: 497/09, 19.7.2012.

Krytatos v. Yunanistan, Başvuru No: 41666/98, 22.5.2003.

Moreno Gomez v. İspanya, Başvuru No: 4143/02, 16.11.2004.

Okyay ve Diğerleri v. Türkiye, Başvuru No: 36220/97, 12.07.2005.

Öçkan ve Diğerleri v. Türkiye, Başvuru No: 46771/99, 28.03.2006. 
Öneryıldız v. Türkiye, Başvuru No: 48939/99, 30.11.2004.

Powell ve Rayner v. Birleşik Krallık, Başvuru No: 9310/81, 21.02.1990.

Tatar v. Romanya, Başvuru No: 67021/01, 06.07.2009.

Taşkın ve Diğerleri v. Türkiye, Başvuru No: 46117/99, 10.11.2004.

Zander v. İsveç, Başvuru No: 14282/88, 25.11.1993.

\section{Anayasa Mahkemesi Kararları}

Binali Özkaradeniz ve Diğerleri, Başvuru No: 2014/4686, 1.2.2018.

D. Ö. Başvurusu, Başvuru No: 2014/3735, 12.06.2018.

Hüseyin Tunç Karlık ve Zahide Şadan Karluk, Başvuru No: 2013/6587, 24.3.2016.

Mehmet Bolat ve Diğerleri, Başvuru No: 2013/5974, 10.03.2016.

Mehmet Kurt, Başvuru No: 013/2552, 25.02.2016. 